\title{
Empirically Based Rainfall Threshold for Landslides Occurrence in Cameron Highlands, Malaysia
}

\author{
Abdul Muaz Abu Mansor Maturidi ${ }^{1}$, Norhidayu Kasim ${ }^{1, *}$, Kamarudin Abu Taib $^{2}$, \\ Wan Nur Aifa Wan Azahar ${ }^{1}$, Husna Ahmad Tajuddin ${ }^{3}$ \\ ${ }^{1}$ Department of Civil Engineering, International Islamic University of Malaysia, 53100 Gombak, Malaysia \\ ${ }^{2}$ Department of Civil and Structural Engineering, National University of Malaysia, 43600, Bangi, Malaysia \\ ${ }^{3}$ Department of Biotechnology Engineering, International Islamic University of Malaysia, 53100 Gombak, Malaysia
}

Received October 29, 2020; Revised December 4, 2020; Accepted December 30, 2020

\section{Cite This Paper in the following Citation Styles}

(a): [1] Abdul Muaz Abu Mansor Maturidi, Norhidayu Kasim, Kamarudin Abu Taib, Wan Nur Aifa Wan Azahar, Husna Ahmad Tajuddin, "Empirically Based Rainfall Threshold for Landslides Occurrence in Cameron Highlands, Malaysia," Civil Engineering and Architecture, Vol. 8, No. 6, pp. 1481 - 1490, 2020. DOI: 10.13189/cea.2020.080629.

(b): Abdul Muaz Abu Mansor Maturidi, Norhidayu Kasim, Kamarudin Abu Taib, Wan Nur Aifa Wan Azahar, Husna Ahmad Tajuddin (2020). Empirically Based Rainfall Threshold for Landslides Occurrence in Cameron Highlands, Malaysia. Civil Engineering and Architecture, 8(6), 1481 - 1490. DOI: 10.13189/cea.2020.080629.

Copyright $\mathrm{C} 2020$ by authors, all rights reserved. Authors agree that this article remains permanently open access under the terms of the Creative Commons Attribution License 4.0 International License

\begin{abstract}
High-intensity rainfall has been recognized as the main factor of the landslide events in Cameron Highlands. Locating at an abrupt altitude with high intensity rainfall annually caused many attempts of slope failures in this area. This catastrophe weakens the socio-economy and situates the people of Cameron Highlands in difficulty since they lost their source of income. The application of the early warning system is one of the effective methods to reduce the losses from this unforeseen circumstance. It could be coordinated by developing a dependable rainfall intensity-duration (I-D) threshold for estimating the shallow landslide. By identifying twelve historical landslides in Cameron Highlands, the important variables from the rainfall intensity-duration parameter can be acquired. The proposed empirical rainfall intensity-duration (I-D) threshold for Cameron Highlands has been figured out as $I=29.09 D^{-0.075}$ ( $\mathrm{I}=$ rainfall intensity in $\mathrm{mm} / \mathrm{hr}$ and $\mathrm{D}=$ duration in hour). Furthermore, to identify the formulation of I-D threshold from other regions, a comparison has been carried out by identifying the I-D threshold proposed by various researchers, which shows a reasonably higher value for the I-D thresholds of Cameron Highlands. This trend occurs due to the fact that rainwater requires more time to adequately seep into the thicker layer of soil in order to trigger the slope failure.
\end{abstract}

Keywords Landslide, Rainfall Intensity-Duration Threshold, Rainfall Threshold, Early Warning System,
Cameron Highland, Empirical Correlation

\section{Introduction}

Surrounded by hilly areas and experience a relatively high amounts of rainfall lays Cameron Highlands at a high risk of a landslide [1]. Located at the coordinate of

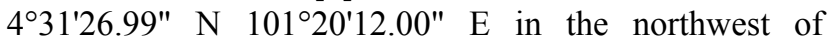
Pahang, Cameron Highlands cover the area of $728 \mathrm{~km}^{2}$ and the elevation of $1829 \mathrm{~m}$ above mean sea level. The geological, geomorphology and hydrological factors significantly contribute to the slope failure. Moreover, having a cold weathering condition gives an opportunity to the local people of Cameron Highlands to make benefits from two primary sectors, which are agriculture and tourism. This leads to the rapid development of this area, which increases the land use and contributes to soil erosion and landslide occurrences [2].

This region experiences a huge variation in climate that is likely to trigger the soil slips episode. Situated in Peninsular Malaysia and experiencing hot and humid weather annually due to close proximity to the equator, Cameron Highlands is susceptible to a high amount of rainfall thus causing many landslide incidents to occur throughout the year [1]. Cameron Highlands recorded the highest daily rainfall in Malaysia for almost 278 days in 
2017 according to the Annual Report 2017 issued by the Malaysian Drainage and Irrigation Department [3]. This indicates the vulnerability of the Cameron Highlands to the shallow landslide that is triggered by extreme precipitation.

The landslides have resulted in a huge loss to the local people [4]. The agricultural and tourism sector are affected badly by the landslide occurrence in Cameron Highlands. Those local people who run the agriculture activity have faced numerous damages to their plantation. Likewise, for the tourism sector, the number of visitors has drop-down since this kind of disaster will put their lives in danger. This indirectly weakens the socio-economical sector of this area.

Hence, there comes a necessity to implement a mechanism of landslide early warning system for alerting the agency regarding the possibilities of upcoming slope failure. Establishing an empirical Intensity-Duration (I-D hereinafter) threshold can be undertaken to initiate the early warning system [5]. It can be accomplished by correlating the rainfall intensity-duration with the historical landslide events [6]. The utilization of meteorological data in the analysis is beneficial since it can determine the incorporating factor of landslide (geology, morphology etc.,) instead of mere hydrological factor. In general, the rainfall analysis is not limited to the purpose of landslide only but it is also applicable for various application such as flood analysis and calculation of rainfall volume for the purpose of water harvesting as shown by the study carried out by Pudyastuti et al [7].

The developed empirical I-D threshold could be integrated into the landslide early warning system, which later would allow the authorities to conduct safety precautions and practice early prevention from the impending disaster. In this era of Industrial Revolution of 4.0 , the application of landslide early warning systems can be realized through advanced and modern technologies such as GIS, imagery satellite, and sophisticated sensors [8]. However, it still requires some coordination and validation to reduce the error and uncertainty that will lead to False Alarm or Missed Alarm later. Nevertheless, this study is going to comprehend the approach to develop the ideal concept of the rainfall threshold of empirical Intensity-Duration (I-D), by looking into the studies around the globe.

\section{Materials and Methods}

\subsection{Methodology}

Generally, most of the current rainfall thresholds were developed by the practical or statistical method of the relationship between the rainfall intensity-duration (I-D). Practical method is carried out by directly correlating the rainfall intensity and rainfall duration that could initiate the landslide occurrence, of which the result is obtained by drawing the threshold line at lower empirical data [9]. Whereas, applying rigorous statistical method such as Bayesian inference or Frequentist method can come up with the credible I-D threshold as well. Hence, this study is carried out to portray the practical method for developing rainfall Intensity-Duration (I-D), since it looks more appropriate and feasible.

Subsequently, identifying the I-D relationship and the analysis of rainfall parameters from each case are conducted to determine the relevant variables such as the maximum rainfall intensity $(\mathrm{mm} / \mathrm{hr}$ ) and the series of rainfall, which represents the duration (hour). The obtained data are presented in logarithmic scale in the form of scatter plot to establish the empirical I-D threshold. The best fit line is generated from the sample plot by adapting the power law regression, thus giving the values of the coefficient $\alpha$ and $\beta$ from the computation. Then, the threshold is defined by emulating the best fit line and being laid down at the lowest plot sample of the intensity that have triggered the landslide. The result is aimed to establish the I-D threshold equation to foresee the shallow landslide occurrence in Cameron Highlands territory. The approaches to achieve the objective are being thoroughly explained afterward.

\subsubsection{Landslide Data}

The data collection initiates with acquiring the landslide data. The landslide data are accessible from the authentic sources illustrated by newspaper article, technical report or the online records that come up with the information regarding the historical soil slips event (e.g. date and time). Additionally, the thorough information of the landslide cases in Cameron Highlands including the cause of landslide and the number of casualties are being procured from the authority of the Slope Engineering Unit, Public Works Department of Malaysia (PWD). For this study, twelve historical shallow landslide events in Cameron Highlands have been selected as depicted in Table 1.

\subsubsection{Rainfall Data}

Subsequently, the following task is to retrieve the meteorological data from the hydrological stations within the radius of $5 \mathrm{~km}$ to $15 \mathrm{~km}$ from the location of failure [10]. The rainfall data are selected based on the time and date of the landslide events. Hence, the adequate meteorological data (hourly rainfall and duration) have been retrieved from the Drainage and Irrigation Department (DID) or Malaysian Methodology Department (MMD) subject to the availability of the data. The specific analyses of rainfall event that have triggered the landslide are being carried out to extract pertinent parameters for establishing the I-D threshold, and it is being performed by using Spreadsheet or Microsoft Office Excel. 


\subsubsection{Rainfall Data Analysis of Rainfall Parameter}

Before developing the empirical I-D threshold, the rainfall data are being scrutinized thoroughly to obtain accurate parameters. Fig. 1 shows the guidelines to analyse the intensity-duration graph. The maximum rainfall intensity and series of rain (rainfall duration) are extracted from the measurement of hourly rainfall data for previous days before the event. The series of rain are measured from the initiation of rain after considering at least 24 consecutive hours of inter-event period without rainfall. The approach is applied to determine the impact of soil infiltration to the occurrence of landslide, since some landslides might occur during short intense storm or with the influence of antecedent rainfall. The series of rain are defined in terms of duration, where the time elapsed from the starting of a series of rain to the landslide event is being acquired. On the other hand, the maximum rainfall intensity, expressed in $\mathrm{mm} / \mathrm{hr}$, is the maximum intensity in the series of rain. The same approach is conducted for each case, that aims to acquire the pertinent variables to develop the I-D threshold later.

\subsubsection{Developing Empirical Intensity-Duration (I-D) Threshold}

Post-analysis of rainfall parameters for the selected twelve cases of landslide brings to the development of the empirical Intensity-Duration (I-D) threshold. Two acquired values, which are Intensity $(\mathrm{mm} / \mathrm{hr})$ and Duration (hour) are being utilised to outline the log-log graph, where the Intensity $(\mathrm{mm} / \mathrm{hr})$ represents the ordinate axis, while the Duration (hour) indicates the abscissa axis.

Generating the scatter plot for both parameters in the logarithmic scale graph, will result in the best-fit line of the graph. The best-fit line needs to comply with the power-law equation and subsequently represents the threshold value. Ideally, the best-fit line is being computed from the correlation of plot sample. Thus, the I-D threshold is being presented accordingly by emulating the best-fit line and laying it at the lowest data (Figure 2). This relatively isolates the occurrence and non-occurrence of landslides.

Moreover, threshold value will represent the general equation in (1) succeeded by Nikolopoulos et al. [9] as follows:

$$
I=\alpha D^{-\beta}
$$

Where the rainfall intensity, $I$ is expressed in $\mathrm{mm} / \mathrm{h}$, rainfall duration, $\mathrm{D}$ is in (hour), while the constant values of $\alpha$ and $\beta$ determine the characteristics of the threshold.
The developed I-D threshold is able to establish the minimum intensity required to trigger the landslide in Cameron Highlands.

\subsubsection{Comparison with Empirical Intensity-Duration (I-D) Threshold Around the Globe}

The developed I-D threshold is being compared with the worldwide threshold obtained by various researchers. In order to make the comparison, the threshold values are being acquired from each study presented in the relevant literatures. Portraying the thresholds in a one-single graph then, will indicate the divergence of results from different researches. The criteria of comparison are represented in terms of the constant value and the steepness of the threshold. This also will discover the minimum rainfall intensity that could trigger the landslide with the specific rainfall duration.

\subsection{Study Area}

Located at the coordinates of $4^{\circ} 31^{\prime} 26.99^{\prime \prime} \mathrm{N}$ $101^{\circ} 20^{\prime} 12.00^{\prime \prime} \mathrm{E}$ in the northwest of Pahang, Cameron Highlands covers the area of $728 \mathrm{~km}^{2}$ at an elevation of $1829 \mathrm{~m}$ above sea level (Figure 3). Cameron Highlands is surrounded by the mountainous landform and the factors of geological formation, morphology, and climate affect greatly on the landslide occurrence. Located on the eastern side of the main-belt range, the regional geological of Cameron Highlands is predominantly formed by granitic formation known as Post-Triassic-Mesozoic [1]. However, the Silurian-Ordovician typical of metamorphic rocks that comprise schist, phyllite, limestone, and sandstone also covers a few regions in the Cameron Highlands area as shown in Fig. 4.

The morphology features of Cameron Highland comprise of alternate valley and ridge that are worked for the agriculture sector or sideway slope. The high demand in land use had threatened the steep-sided area and caused numerous slope failures either on a minor or severe scale. Additionally, the slope geometry can also affect the instability. The exploration of the slope with the extensive cutting for farming purpose increases the susceptibility of landslide with the negligence of slope geometry (e.g. slope angle). In addition, the innate or artificial pool water zone that intended to irrigate the vegetation had been stranded and turned up the early sign of tension cracks. All these features can contribute to the slope movement, and it became worse when the extreme showers hit the surrounding area. 
Time (Hour)

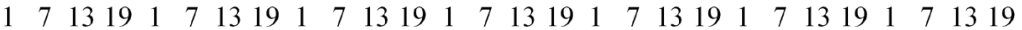

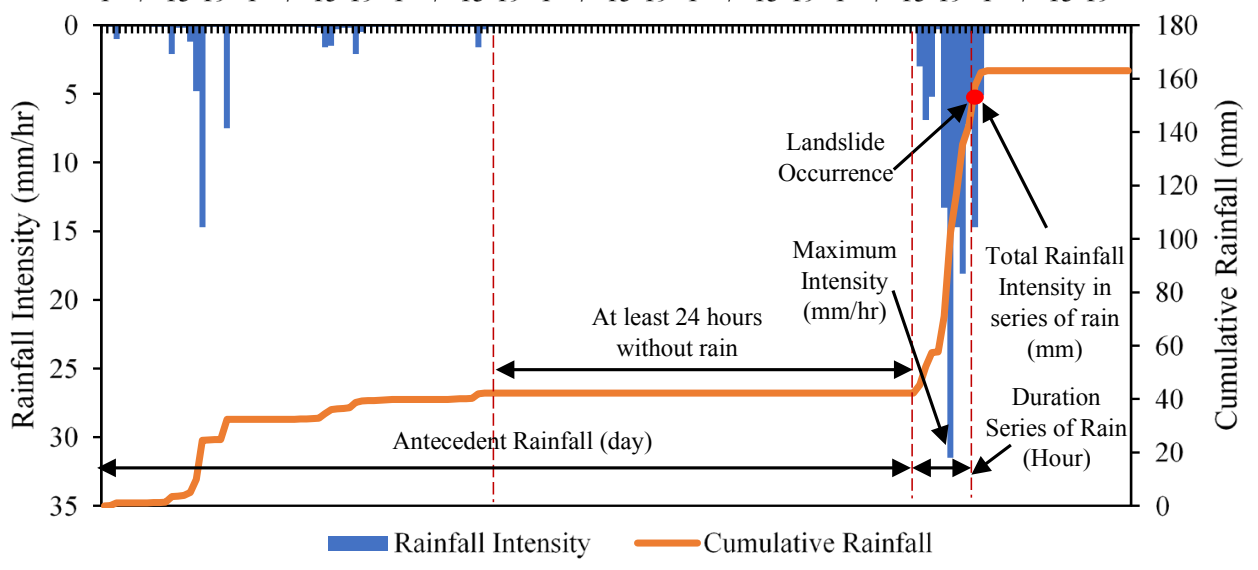

Figure 1. Guideline in Analysis of Rainfall Intensity-Duration

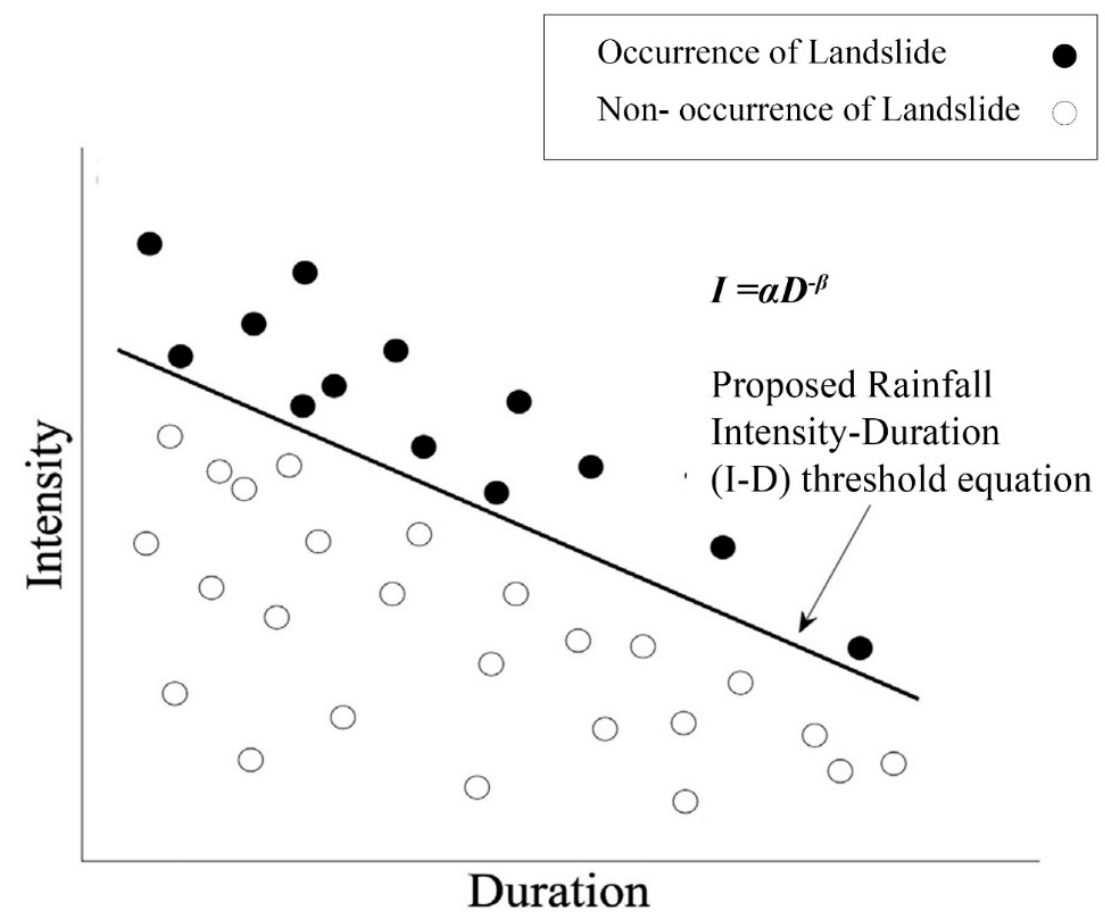

Figure 2. Rainfall Intensity-Duration (I-D) Threshold Graph [9]

\subsection{Rainfall Data}

The hourly collection of adequate meteorological data from the Malaysian Drainage and Irrigation Department (DID) authority would later result in a credible scientific I-D threshold. In the actual approach, the rainfall data must be taken exactly at the position of the landslide. Acquiring that kind of info, though, is impractical. Therefore, referring to Melillo et al. [10], rainfall data must be taken from the rain gage station close to the landslide occurrence subject to morphological research area circumstances and rain gage density. Melillo et al. [10] mentioned that a radius of $5 \mathrm{~km}$ rain gauge is reasonable for the location with uneven altitude such as hilly areas, while the $15 \mathrm{~km}$ rain gauge is the appropriate distance for flat area. Therefore, it is convenience to have a radius of rain gauge station between $5 \mathrm{~km}$ and $15 \mathrm{~km}$ for this study. Table 2 shows the previous shallow landslide with the selected rain gauge including the station name, coordinate, and its distance from the failure site. 


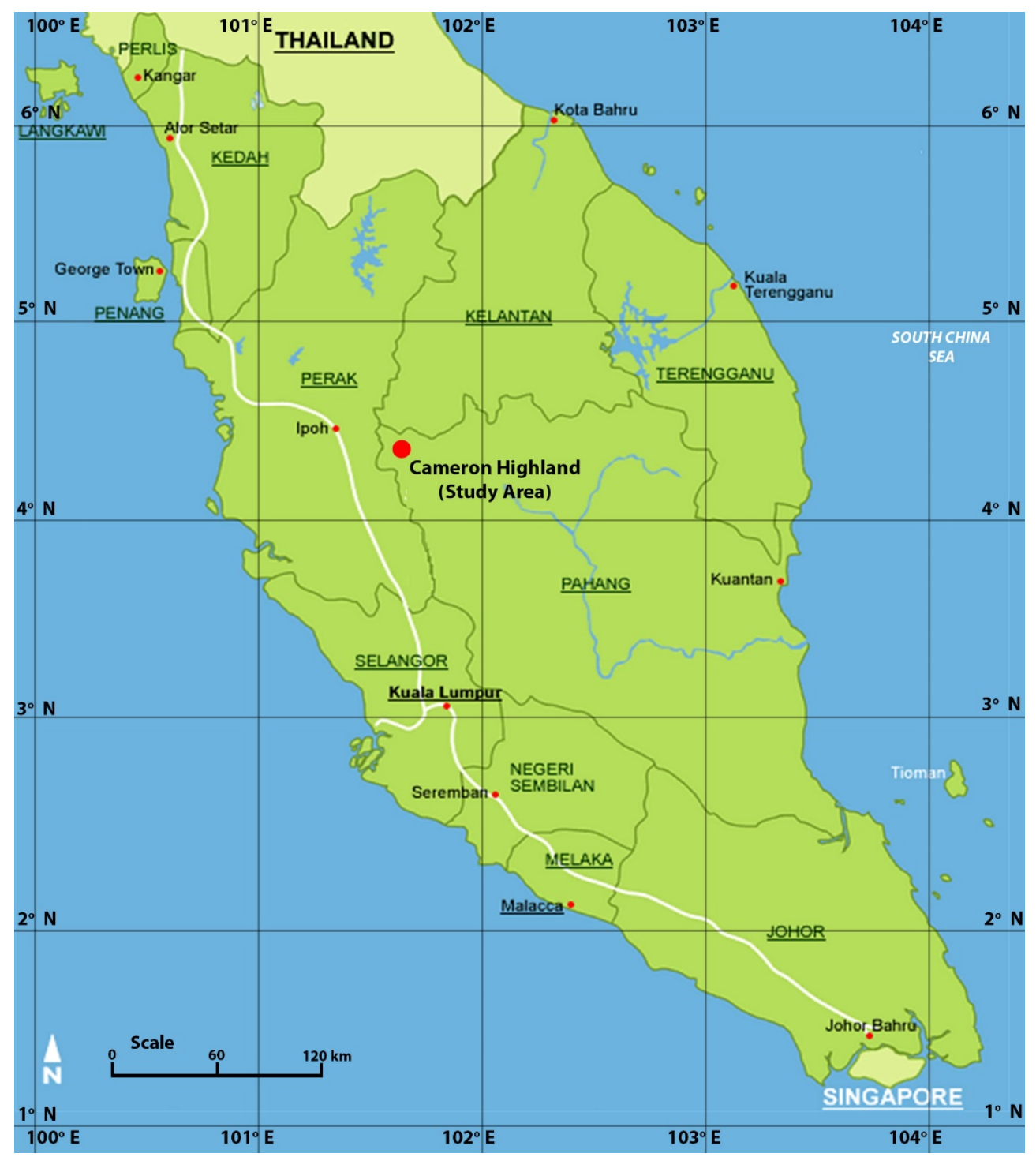

Figure 3. Location of Cameron Highlands [11] 


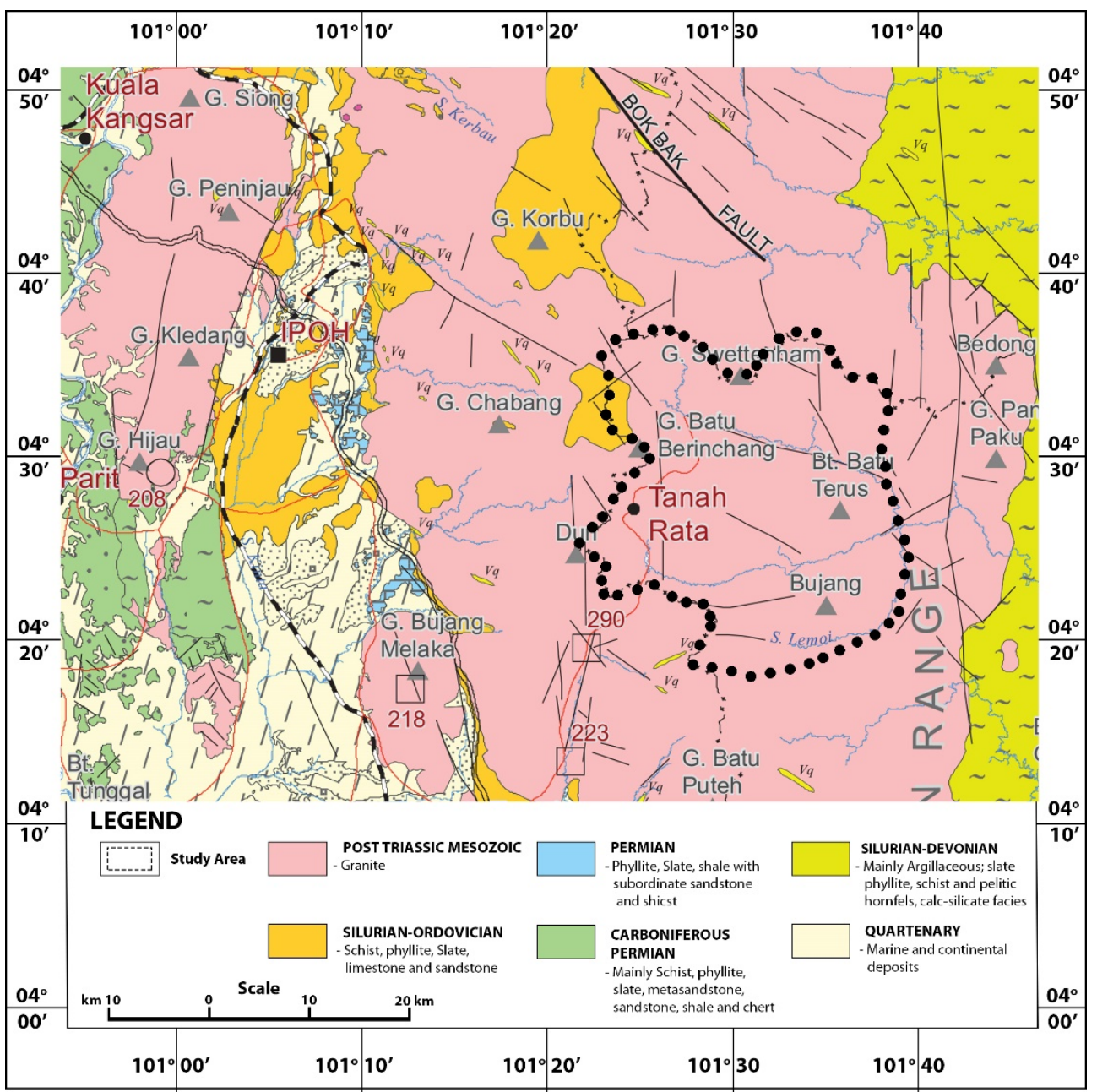

Figure 4. Geological Structure of Cameron Highlands [12]

Table 1. Information of historical shallow landslide events in Cameron Highland

\begin{tabular}{|c|c|c|c|c|c|}
\hline No & Location of Landslide in Cameron Highlands & Date & Time & Casualties & $\begin{array}{c}\text { Loss of } \\
\text { Properties }\end{array}$ \\
\hline 1 & $51^{\text {st. }}$ Mile, Kuala Terla Road, Raja Village & $\begin{array}{l}\text { Oct } 24^{\text {th }}, \\
2018\end{array}$ & $1700 \mathrm{Hrs}$. & - & $\begin{array}{l}\text { Road, Car } \\
\text { Damage }\end{array}$ \\
\hline 2 & $78.8^{\text {th. }} \mathrm{KM}, 49^{\text {th. }}$ Mile, Tiga Village, Kuala Terla & Oct $4^{\text {th }}, 2018$ & $1000 \mathrm{Hrs.}$ & 3 Killed & House Damage \\
\hline 3 & $\begin{array}{c}\text { Flower Farm, 49th. Mile, Kuala Terla, Raja } \\
\text { Village }\end{array}$ & $\operatorname{Jan} 25^{\text {th }}, 2017$ & 0300 Hrs. & 1 Killed & Farm Damage \\
\hline 4 & TNB Sharples Rest House, Tanah Rata & $\begin{array}{l}\text { Dec } 25^{\text {th }}, \\
2016\end{array}$ & 1530 Hrs. & - & $\begin{array}{l}\text { House, Road } \\
\text { Damage }\end{array}$ \\
\hline 5 & Terisu Post & Jan $14^{\text {th }}, 2016$ & $0800 \mathrm{Hrs}$. & 1 Killed & Farm Damage \\
\hline 6 & Ringlet Town, Bertam Valley & Nov $5^{\text {th }}, 2014$ & 1900 Hrs. & 2 Killed & $\begin{array}{l}\text { House, Farm, } \\
\text { Road damage }\end{array}$ \\
\hline 7 & 46th. Km, Brinchang-Tringkap Road & $\begin{array}{c}\text { Dec } 30^{\text {th }} \\
1014\end{array}$ & $0530 \mathrm{Hrs}$. & 2 Killed, 1 Injured & House Damage \\
\hline 8 & Sultan Abu Bakar Brinchang Road & $\begin{array}{c}\text { Nov } 10^{\text {th }}, \\
2013\end{array}$ & 0630 Hrs. & 2 Injured & $\begin{array}{l}\text { Workshop and } \\
\text { Car Damage }\end{array}$ \\
\hline 9 & $\begin{array}{c}\text { Ruil River Aboriginal Community Village, } \\
\text { Brinchang }\end{array}$ & Aug 7, 2011 & 1730 Hrs. & 7 Killed, 2 Injured & House damage \\
\hline 10 & Kuala Terla & $\begin{array}{c}\text { Oct } 10^{\text {th }}, \\
1996\end{array}$ & $1500 \mathrm{Hrs}$. & 3 Killed & - \\
\hline 11 & $\begin{array}{c}\text { Cameron Highlands (precise location } \\
\text { not-identified ) }\end{array}$ & Dec $1^{\text {st }}, 1995$ & 2130 Hrs. & 7 Killed & - \\
\hline 12 & Kea Farm, Tringkap & $\begin{array}{c}\text { Oct } 24^{\text {th }}, \\
1995\end{array}$ & $1700 \mathrm{Hrs}$. & 1 Killed & - \\
\hline
\end{tabular}


Table 2. List of the Selected Rain Gauge with detailed station name, coordinate and location distant of landslide

\begin{tabular}{|c|c|c|c|c|}
\hline No & $\begin{array}{c}\text { Landslide Location in Cameron } \\
\text { Highlands area }\end{array}$ & Rain Gauge Station & $\begin{array}{c}\text { Coordinate } \\
\text { (Latitude, Longitude) }\end{array}$ & $\begin{array}{c}\text { Rain Gauge and } \\
\text { Landslide Scene } \\
\text { Distance (km) }\end{array}$ \\
\hline 1 & $51^{\text {st. }}$ Mile, Kuala Terla Rd., Raja Village. & Palas River Tea Plantation & $\begin{array}{l}4^{\circ} 31^{\prime} \mathrm{N} \\
101^{\circ} 25^{\prime} \mathrm{E}\end{array}$ & 3.4 \\
\hline 2 & $\begin{array}{c}78.8^{\text {th }} \mathrm{Km}, 49^{\text {th. }} \text { Mile, Tiga Village, Kuala } \\
\text { Terla } \\
\end{array}$ & Palas River Tea Plantation & $\begin{array}{l}4^{\circ} 31^{\prime} \mathrm{N}, \\
101^{\circ} 25^{\prime} \mathrm{E}\end{array}$ & 3.5 \\
\hline 3 & $\begin{array}{c}\text { Flower Farm, } 49^{\text {th. }} \text { Mile, Kuala Terla, Raja } \\
\text { Village }\end{array}$ & $\begin{array}{l}\text { Boh Plantation (South } \\
\text { Portion) }\end{array}$ & $\begin{array}{l}4^{\circ} 26^{\prime} 55^{\prime \prime} \mathrm{N} \\
101^{\circ} 27^{\prime} 10^{\prime \prime} \mathrm{E}\end{array}$ & 11.2 \\
\hline 4 & TNB Sharples Rest House, Tanah Rata & Brinchang Hill & $\begin{array}{l}4^{\circ} 31^{\prime} \mathrm{N} \\
101^{\circ} 23^{\prime} \mathrm{E}\end{array}$ & 2.4 \\
\hline 5 & Terisu Post & $\begin{array}{l}\text { Boh Plantation (Factory } \\
\text { area) }\end{array}$ & $\begin{array}{l}4^{\circ} 27^{\prime} 05^{\prime \prime} \mathrm{N} \\
101^{\circ} 25^{\prime} 30^{\prime \prime} \mathrm{E}\end{array}$ & 11.5 \\
\hline 6 & Ringlet Town, Bertam Valley & $\begin{array}{l}\text { Boh Plantation (Boh } \\
\text { Portion) }\end{array}$ & $\begin{array}{l}4^{\circ} 26^{\prime} 30^{\prime \prime} \mathrm{N} \\
101^{\circ} 26^{\prime} 40^{\prime \prime} \mathrm{E}\end{array}$ & 5.7 \\
\hline 7 & $46^{\text {th. }} \mathrm{KM}$, Brinchang-Tringkap Road & Palas River Tea Plantation & $\begin{array}{l}4^{\circ} 31^{\prime} \mathrm{N} \\
101^{\circ} 25^{\prime} \mathrm{E}\end{array}$ & 1.8 \\
\hline 8 & Sultan Abu Bakar Road, Brinchang & $\begin{array}{l}\text { Mardi Station Cameron } \\
\text { Highlands }\end{array}$ & $\begin{array}{l}4^{\circ} 27^{\prime} 00.0^{\prime \prime} \mathrm{N} \\
101^{\circ} 25^{\prime} 12^{\prime \prime} \mathrm{E}\end{array}$ & 6.3 \\
\hline 9 & $\begin{array}{c}\text { Ruil River Aboriginal Community Village, } \\
\text { Brinchang }\end{array}$ & $\begin{array}{l}\text { Mardi Station Cameron } \\
\text { Highlands }\end{array}$ & $\begin{array}{l}4^{\circ} 27^{\prime} 00.0^{\prime \prime} \mathrm{N} \\
101^{\circ} 25^{\prime} 12^{\prime \prime} \mathrm{E}\end{array}$ & 6.5 \\
\hline 10 & Kuala Terla & Brinchang Hill & $\begin{array}{l}4^{\circ} 31^{\prime} \mathrm{N} \\
101^{\circ} 23^{\prime} \mathrm{E}\end{array}$ & 5.0 \\
\hline 11 & $\begin{array}{l}\text { Cameron Highlands (exact location not } \\
\text { mentioned) }\end{array}$ & Brinchang Hill & $\begin{array}{l}4^{\circ} 31^{\prime} \mathrm{N} \\
101^{\circ} 23^{\prime} \mathrm{E}\end{array}$ & 10.0 \\
\hline 12 & Kea Farm, Tringkap & Brinchang Hill & $\begin{array}{l}4^{\circ} 31^{\prime} \mathrm{N} \\
101^{\circ} 23^{\prime} \mathrm{E}\end{array}$ & 2.9 \\
\hline
\end{tabular}

\section{Results and Discussion}

\subsection{Empirical Intensity-Duration (I-D) Threshold}

Post-analysis of rainfall parameters for the selected twelve cases of landslide brings to the development of the empirical Intensity-Duration (I-D) threshold. Two acquired values, which are Intensity $(\mathrm{mm} / \mathrm{hr})$ and Duration (hour), are tabulated in Table 3. The acquired data are being utilised to outline the log-log graph shown in Fig. 2 before, where the Intensity $(\mathrm{mm} / \mathrm{hr})$ represents the ordinate axis, while the Duration (hour) indicates the abscissa axis.

Generating the scatter plot for both parameters in the logarithmic scale graph, will result in the best-fit line of the graph. The best-fit line needs to comply with the power-law equation and represents the threshold value. Ideally, the best-fit line will be generated between the plot sample. Thus, the I-D threshold will be presented accordingly by emulating the best-fit line and laying it at the lowest data. This relatively isolates the occurrence and non-occurrence of landslides. Moreover, the threshold value will represent in general equation of $I=\alpha D^{-\beta}$ where the constant values of $\alpha$ and $\beta$ are going to determine the characteristics of the threshold. The landslide in Cameron Highlands could be estimated based on the minimum rainfall intensity generated by the I-D threshold. The result of the threshold is shown in Fig. 5.

According to the empirical I-D threshold graph, the threshold value is expressed in (2) as follows:

$$
I=29.09 D^{-0.075}
$$

Among the twelve cases of landslides, the threshold curve evaluates the rainfall duration that induced the slope failure, which is between 7 hours to 236 hours. The rainfall parameters show varying results in Table 3 .

For Cameron Highlands landslides, there are cases of low intensity with high duration, high intensity with low duration, the low intensity with low duration and high intensity with high duration.

For the case of higher rainstorm duration regardless of low or high rainfall intensity, the antecedent rainfall effect contributes a vital role especially when dealing with the soil moisture at the location of failure. This might be affected by different type of soils, where the thicker layer of soil requires more water to saturate the ground layer and rises the pore pressure of soil. Thus, low rainfall intensity might initiate the failure when the soil is already in extreme saturated state, while the saturated soil in allowable steady condition is likely to trigger the failure when the intense precipitation severely hits the prone area of landslide.

On the other hand, the landslide case for shorter period of rainfall occurs when the soil strata are highly saturated in just several hours of storm. The temporary aquifer was formed at the upper ground layer and once it receives high rainfall intensity, it will increase the perched water table and positive pore water pressure thus transform the soil layer into highly saturated state. It will then minimize the shear against the slips surface and eventually lead to the 
initiation of shallow landslip. Meanwhile, the low rainfall intensity for the shorter rainfall duration might be influenced by the antecedent rainfall as well that had generated the temporary aquifer prior to the inter-event period without rainfall.

For the application of the early warning system based on Aleotti [5], the warning line (red dot line) could be determined 10 percent beneath the minimum triggering threshold. Fig. 5 demonstrates the warning level for the landslide which is at the value of $I=26.18 D^{-0.075}$. When the rainfall intensity at specific rainfall duration approach the warning level (e.g. $24.1 \mathrm{~mm} / \mathrm{hr}$ in 3 hours rainfall), the authorities could conduct the pre-emptive measures such as notifying the public regarding the upcoming disaster through the media platform and evacuate the civilians at the prone area of landslide in order the reduce the losses against the catastrophe.

Table 3. The rainfall parameters extracted from each rainfall measurement

\begin{tabular}{|c|c|c|c|}
\hline No & $\begin{array}{c}\text { Landslide } \\
\text { Date }\end{array}$ & $\begin{array}{c}\text { Max. Rainfall } \\
\text { Intensity (mm/hr) }\end{array}$ & $\begin{array}{c}\text { Duration } \\
\text { (hour) }\end{array}$ \\
\hline 1 & $24-J a n-18$ & 25.5 & 57 \\
\hline 2 & $14-$-Oct-18 & 42.6 & 12 \\
\hline 3 & $25-J a n-17$ & 15.1 & 91 \\
\hline 4 & 25 -Dec-16 & 39.3 & 211 \\
\hline 5 & $14-J a n-16$ & 20.7 & 9 \\
\hline 6 & 30-Dec-14 & 13.2 & 236 \\
\hline 7 & 5-Nov-14 & 31.5 & 7 \\
\hline 8 & 10 -Nov-13 & 27.5 & 106 \\
\hline 9 & 7-Aug-11 & 26.1 & 22 \\
\hline 10 & $10-$-Oct-96 & 13.8 & 229 \\
\hline 11 & 1 -Dec-95 & 12.4 & 8 \\
\hline 12 & 24-Oct-95 & 17.1 & 150 \\
\hline
\end{tabular}

\subsection{Comparison with selected I-D Thresholds Worldwide}

Upon development of the I-D threshold, it is appropriate to come up with a comparison with other I-D thresholds proposed by various researchers worldwide. The first comparison of I-D threshold had been made by Caine [13]. He conducted a study by comparing I-D threshold for the shallow landslides or debris flows and established the global I-D threshold. On the other hand, according to Guzzetti et al. [14], different climate regions indicate a different threshold value. It is proven in this study, where Cameron Highlands possessed a prolonged period with a moderate rainfall intensity to cause slope failure. However, other regions in Peninsular Malaysia require short intense rainfall to trigger the landslides [15].

There are six selected thresholds from different regions and areas shown in Fig. 6. According to the figure, the I-D threshold of Cameron Highlands indicates the least steepness of threshold at first glance. This indicates the rainfall intensities that trigger the landslides are in a small gap despite the rainfall durations. At first, the Cameron Highlands threshold is compared with the Peninsular Malaysia threshold proposed by Norhidayu et. al. [15] since both thresholds appeared in the same region. The Peninsular Malaysia threshold shows a greater threshold value compared to this study. The main reason is that the I-D threshold of Peninsular Malaysia is specialized for debris flow or shallow landslide. Therefore, high intensity rainfall with a low rainfall duration is required to trigger the landslide for the Peninsular Malaysia threshold. Moreover, the smaller exponent $(-0.075)$ is produced by the Cameron Highlands threshold compared to other thresholds worldwide for more than -0.1 as shown in Table 4 . The negative sign of exponents denotes the slope steepness that falls from left to right. Logically, the steepness of the threshold is determined by the exponents. It is proven, even though Cameron Highlands has the smallest value of exponent compared to other worldwide thresholds, but it took the mid place in the comparison.

For the overall comparison between Cameron Highlands threshold and other worldwide thresholds, the indication is that the I-D threshold is reasonably higher for Cameron Highlands. As mentioned before, the Cameron Highlands threshold conquers the mid place in the comparison, where the third upper threshold is taken by Dahal and Hasegawa [6], Pereira and Zêzere [16] and Norhidayu et. al [15]. Meanwhile, the third lower is occupied by Aleotti [5], Guzzetti et al. [14] and Caine [13]. Caine [13] recorded the lowest threshold since he established a global threshold. Cameron Highlands shows a quite higher threshold, similar to the Peninsular Malaysia threshold in general. One of the reasons is that Malaysia experiences a monsoon season with a lot of rain annually causing a lot of landslide events [15]. Hence, the water requires more time to adequately seep into the soil with the thicker layer that it possesses to initiate the soil slips event. The comparisons with some other threshold equations are demonstrated in Table 4. 


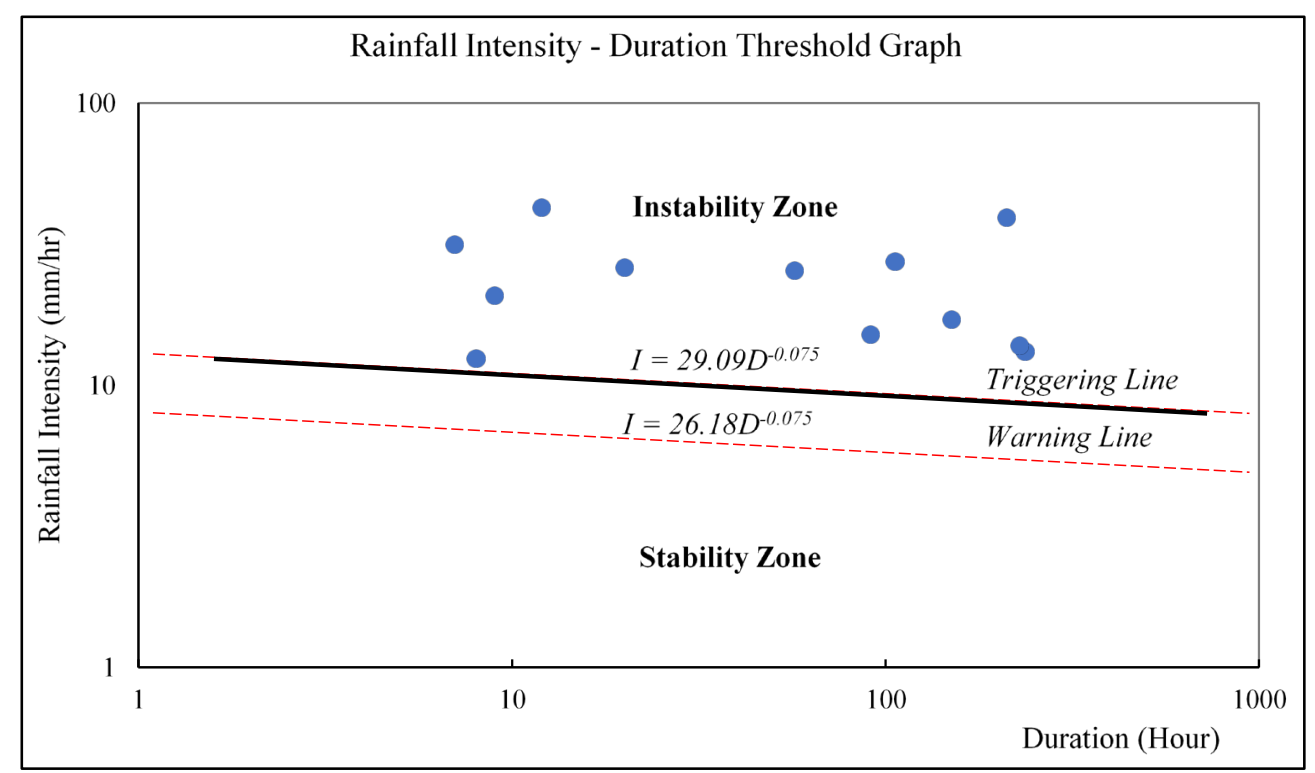

Figure 5. Intensity-Duration Threshold Graph for the landslide occurrence in Cameron Highlands area

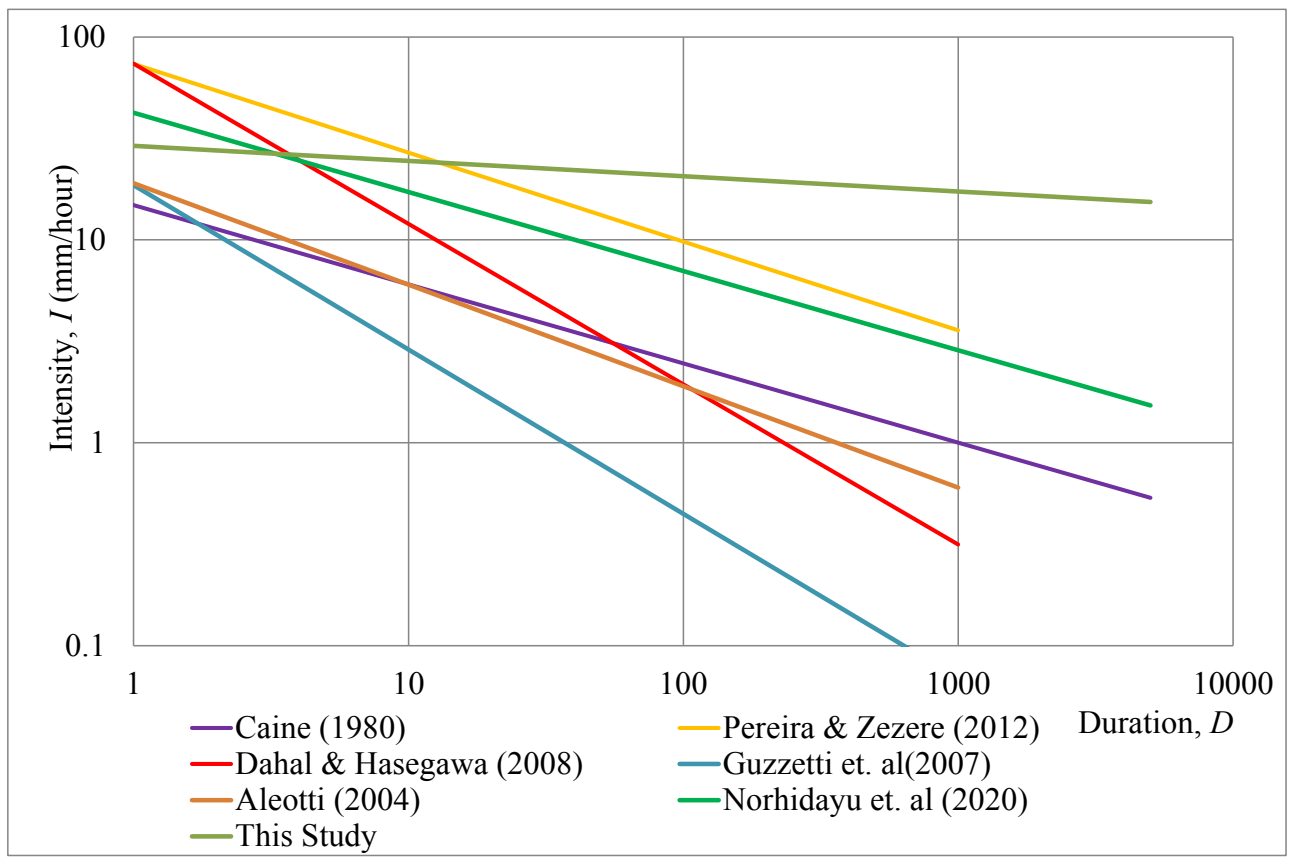

Figure 6. Comparison of developed I-D threshold with worldwide threshold

Table 4. Empirical I-D threshold from various studies

\begin{tabular}{ccc}
\hline Researchers & Area & Equation \\
\hline $\begin{array}{c}\text { Norhidayu et al } \\
(2020)\end{array}$ & $\begin{array}{c}\text { Peninsular } \\
\text { Malaysia } \\
\text { Pereira \& Zezere } \\
\text { (2012) } \\
\text { Douro Valley, } \\
\text { Portugis }\end{array}$ & $I=42.30 D^{-0.392}$ \\
(2008) & $\begin{array}{c}\text { Nepal Himalaya } \\
\text { Cadses mid }\end{array}$ & $I=73.72 D^{-0.438}$ \\
Guzzetti et al (2007) & $\begin{array}{c}\text { 1atitude climate } \\
\text { dor D<300h } \\
\text { Piedmont region, } \\
\text { Italy }\end{array}$ & $I=18.6 D^{-0.79}$ \\
Aleotti (2004) & $\begin{array}{c}\text { World } \\
\text { Caine (1980) }\end{array}$ & $I=19 D^{-0.50}$ \\
\hline
\end{tabular}

\section{Conclusion}

This paper successfully comprehended the approach for developing the rainfall threshold of Cameron Highland. The analysis of specific rainfall event that had triggered the slope failure had been carried out, which aimed to extract the important rainfall variables namely rainfall intensity and duration. Then, the empirical I-D threshold to estimate the initiation of slope was developed and expressed as, $I=29.09 D^{-0.075}$. According to the threshold equation, a $25 \mathrm{~mm} / \mathrm{hr}$ rainfall could trigger the landslide for the duration of rainfall less than 10 hours, while the slope failure can occur over 24 hours if the rainfall intensity is found at $22 \mathrm{~mm} / \mathrm{hr}$. 
Then, a comparison was performed between the developed I-D threshold and the selected global threshold and shows a reasonably higher value for the Cameron Highlands. The higher threshold is due to the fact that more time is required for the water to seep adequately into the soil with the thicker layer that it possesses in order to trigger the slope failure. The developed I-D threshold may be used in the landslide early warning system, that later would allow the authority to conduct the pre-emptive actions against the soil slips event so that the dreadful consequences from shallow landslide could be alleviated.

\section{Acknowledgements}

The research has been carried out under Fundamental Research Grant Scheme (FRGS-RACER) project RACER/1/2019/TK01/UIAM//1 provided by the Ministry of Education of Malaysia. The authors wish to thank all the staff of Research Development Division, Slope Engineering Branch, Public Works Department of Malaysia for providing the necessary landslide data and Drainage and Irrigation Department of Malaysia for providing the necessary rainfall data.

\section{REFERENCES}

[1] B. Pradhan, S. Lee, Regional landslide susceptibility analysis using back-propagation neural network model at Cameron Highland, Malaysia. Landslides, Vol.7, No.1, 1330, 2010, https://doi.org/10.1007/s10346-009-0183-2

[2] A.F. Abdullah, W. Aimrun, N. M. Nasidi, K. Hazari, L. M Sidek, Z. Selamat, Modelling erosion and landslides induced by farming activities at Hilly Areas, Cameron Highlands, Malaysia, Jurnal Teknologi, N. M., Vol.81, No.6, 195-204, 2019, https://doi.org/10.11113/jt.v81.13795

[3] Meteorological Malaysia Department, Meteorological Malaysia Department: annual report 2017, Kuala Lumpur, Malaysia, 2017.

[4] C. N. Weng, A. A. Rahim, N. Samat, J. M. Jahi, Development and management issues of highland in Malaysia, The 2nd Regional Seminar on Environmental Management in Malay World, 1-20, 2009.

[5] P. Aleotti, A warning system for rainfall-induced shallow failures, Engineering Geology, Vol.73, No.3-4, 247-265, 2004, https://doi.org/10.1016/j.enggeo.2004.01.007

[6] R. K. Dahal, S. Hasegawa, Representative rainfall thresholds for landslides in the Nepal Himalaya. Geomorphology, Vol.100, No.3-4, 429-443, 2008, https://doi.org/10.1016/j. geomorph.2008.01.014

[7] P.S. Pudyastuti, F. Kalista, G.D. Wibowo, H.S. Budinetro, Small Scale Integrated Sustainable Roof Design (Case Study in Surakarta City), Civil Engineering and Architecture, Vol.8, No.4, 500-506, 2020,https://doi.org/10.13189/cea.20 20.080413

[8] S.E. Taşabat, T Özçay, S. Sertbaş, E. Akca, Industry 4.0 Application on Diagnosis Prediction of Construction Machinery: A New Model Approach, Civil Engineering and Architecture, Vol.8, No.4, 404-416, 2020, https://doi.org/ 10.13189/cea.2020.080402

[9] E.I. Nikolopoulos, S. Crema, L. Marchi, F. Marra, F. Guzzetti, M. Borga, Impact of uncertainty in rainfall estimation on the identification of rainfall thresholds for debris flow occurrence. Geomorphology, Vol.221, 286-297. https://doi.org/10.1016/j.geomorph.2014.06.015

[10] M. Melillo, M.T. Brunetti, S. Peruccacci, S.L. Gariano, A. Roccati, F. Guzzetti, A tool for the automatic calculation of rainfall thresholds for landslide occurrence, Environmental Modelling and Software, Vol.105, 230-243, 2018, https://doi.org/10.1016/j.envsoft.2018.03.024

[11] Online Available: Online GIS MAP- Department of Mineral and Geosciences Malaysia, Online available from https://www.jmg.gov.my/add_on/mt/smnjg/tiles/

[12] Online Available: MetMalaysia: Utama, Online available from http://www.met.gov.my/

[13] N. Caine, The rainfall intensity-duration control of shallow landslides and debris flows. Geografiska Annaler A, Vol.62, No.1-2, 23-27, 1980 .

[14] F. Guzzetti, S. Peruccacci, M. Rossi, C.P. Stark, Rainfall thresholds for the initiation of landslides in central and southern Europe. Meteorology and Atmospheric Physics, (2018). Vol.98, No.3-4, 239-267, 2007,https://doi.org/10.1 007/s00703-007-0262-7

[15] K. Norhidayu, K.A. Taib, W.N.A.W Azahar, N.N. Ismail, N.M. Husain, A.B. Ramli, rRainfall intensity-duration induced debris flow in peninsular malaysia. Proceedings of AICCE'19 , 2020 DOI: 10.1007/978-3-030-32816-0_66

[16] S. Pereira, J. Zêzere, Empirically-based rainfall thresholds for debris flow occurrence in the north of Portugal. XII National Conference of Geomorphology, Santander 2012, 109-112, 2012 